\title{
FREE THOUGHT AND THE MUSICIAN
}

Mfusic and religion have often enough been correlated: but as a general rule it would seem that the correlation has been somewhat limited either historically or psychologically. Music has been atyled the handmaid of religion, and, in a sense, truly; the Christian Church gave birth to practically all the great music of the early dawn, and to much of the greatest in the centuries that have followed. But it is too late now to say that "The Church will always be the chief home and school of music for the people." in the words of the distinguished men who recently appealed * for funds for the foundation of a professorship of ecclesiastical music. The correlation has not remained as simple as it. was ; there have been new influences at work, quite apart from those arising from song or drama or purely instrumental composition. And again, the emotional point of view that has been mainly predominant in these attempts at correlation is not lightly and unadvisedly to be taken for granted as the only possible one : seen from another psychological angle, the problems present different aspects, which have their definitely practical as well as theoretical significance. No one will deny that the last generation has seen profoundly important changes in religious thought; whatever the eddies and backwaters, the main stream has run, and still runs, like a cataract. These changes may be very differently regarded by different types of men, all of them equally firm believers in the supremacy of spiritual ideals; some may definitely regret, some may, with the help of such conceptions as that of progressive revelation, steer a middle course, some (among whom I would number myself) may definitely welcome. But in whatever light we may regard these radical refusals of the old allegiances, we shall naturally expect to find their influence in music, which has had in many wajs so intimate a connection with religion. $t$

In our own conntry, which has had, not sltogether fairly bat indubitably, a reputation for national hypocrisy to sustain, religion has affected musical institutions in some specially distinctive ways, positive

- The Times, April 17, 1919.

f On the Aristotelian principle that when a thing has been said once it is herd to say it again differently, I venture to quote the lant three sentences from a lecture of my own included in a composite volume, "Recent Developments in European Thought," issued by the Oxford Oniversity Press. 
and negative; and changes now taken for granted have been the cause, within very recent memory, of agitation little known elsewhere. Our Sunday secular concerts, now everywhere, are little over thirty years old : Samson et Dalila, now one of the most familiar operas, was, only a fow years ago, forcibly styled an oratorio and excluded from Covent Garden, which, again, opened its doors to Salome only after violent opposition now forgotten. Again, those of us whose memories are of older standing will recall the wide vogue of the popular religious song, often straying from its native haunts into the middle of programmes otherwise artistic in aim : its successors may perhaps be no better either musically or verbally, but they are at any rate different, and secular. All these happenings have been in essence deeply symptomatic of a chenge in biblical conceptions, conceptions more paramount here than in countries which, for better or possibly for worse, have lacked Puritan traditions : but development may be preferably traced on wider lines, in the modifications of forms of composition of universel range.

Take the oratorio, in the shape in which it was fixed for the world by Handel : a compromise between the Church and the theatre, depending for its vitality on its connection with matters accepted unquestioningly as literally true and full of powerful non-artistic associations, always edifying, but at the same time free from any pressingly personal appeal to spiritual emotions. In this routine shape, which has been the main line of oratorio-development, it is plain enough that now hardly any composer worth the name is so poor as to do it reverence. It bes gone, side by side with the dominating religious routine that gave it birth.

Brahms' Requiem was, something like half a century ago, the beginning of the end. The composer not only commendeered a purely ecclesiastical designation for his own purposes, but, which was still more important, he himself selected words - on a scale so large as definitely to claim to envisage the whole of the matter in hand-which were parely personal in outlook and divorced from any specifically Christian elements, which, in spite of pressure, he steadfastly refused to add. The work was a definite herald of revolt inasmuch as, while employing the medium of biblical language, it discarded all mechanism whether biblical or ecclesiastical and appesled straight from personal vision to personal intelligence. We may say perhaps that Brahms was (like many another breaker of fresh ground) in one or two respects not altogether logically consistent; but somewhat alien as is the note struck by the "letate Possune," it is a passing-note sufficiently allegorisable. And, anyhow, the main point is clear enough : it is on the expression of individually realised mysticism that the Requiem depends for its spiritual validity, not on association with temporal and spatial happenings provable or disprovable. And the influence has spread steadi'y 
wider and wider : in Brahms' own Schicksalslied and Gesang der Parzen, and in hoste of works by composers many of whom have otherwise had but little hold on him, united by the single but all-important tie that they are settings of grest thoughts on the ultimate things envisaged from every conceivable angle except that of rigid orthodory. Composers may, according to their differing temperaments, swing towards either the right or the left wing of religions thought in their search : they may join forces with poets thousands of miles and of years apart : or they may in the last resort, like Parry, beat out both the words and the music of their own individual outlook on life. But individual it all is : and that is eractly what the routine oratorio was not.

And the genuine conservatives have felt the time-spirit also. Like the radicals, they have broken away from what was virtually indifferentism : they have realised that, whatever the medinm of their own works, they must in spirit attach themselves firmly to the grest line of religious music definitely designed for a place in religions ritual, not a compromise like the routine oratorio, but an unmistakable challenge to the individual sonl. Sincerity, that is the one thing needful. Bome of the words may be loosely called oratorios as before : but no libretti could well be farther apart in spirit than those of Elgar's The Apostles or The Kingdom, and those of Meridelssohn's Elijah or St. Paul, perhaps the most skilful of the older type. The coneervatives have been forced to feel that the day of the old complacency is over, that they must justify their claims : they must take their religions music in deadly earnest if it is to live. It is, in the main, to Catholicism in one or another form-perhaps because it realises with special vividness the urgency of the struggle-that religious music of the conservative type owes its present vitality : Westminster Cathedral, the Schola Cantorum, such Anglican hymn-books as Songs of Syon-these are the rallying-points. Some musicians may feel that, whatever our just admiration for the great plainsong melodies and Palestrina and the rest of the geniuses of the sirteenth century, it is after all in the twentieth that we are living, through no fault or virtue of our own, but as a plain matter of fact : but all must neede be deeply grateful for the ideals of purity and dignity which these conservative reformers, even if perhaps regarding music as something like a mere department of theology, have always steadily upheld.

Nevertheless, the direction of the main current is plain. It is only when a composer has personal sympathies that he is impelled to write religious music of the epiritually conservative outlook : he no longer writes it, so to speak, officielly. Which is in itself a very great change, and implies much more still. It is the music that stays in the old religions pathe that we now ask for a reason for the hope that is in it: 
not, as fifty years ago, the music that breaks away. And we do this satomatically : as it were in our sleep, we have swung round so that whst was once natural seems now to us unnatural, and vice versa. All the great religious music holds its place in virtue of its universally spiritual and artistic force, not by any vitality of its orthodox associations : instinctively we judge it apart from its theology. We may feel indeed that there is a powerful, perhaps a perennial, artistic expressionableness in the varyingly interpreted and emphasised forms of sincerely held supernaturalism, whether seen through the eyes of a child (as in Haydn's Creation) or through those of a grown man : but, in so feeling, we universalise in terms of poetry and art and the humsn spirit, we reject the old paths, which were nothing if not definite and exclusive. We may hear various reasons given why performances of oratorios are less to the forefront, why composers never write them or fail to bring to light sequels, planned years ago, to works once popular, reasons of length, heaviness, or any other quality supposed to be alien to the taste of to-day : bat far above all such subordinate causes must, I am sure, be placed the one all-sufficient cause that to more and more of us, whether or not the fact may be present to consciousness, they deal with things that are dead.

And there are also the practical issues for the individual musician. Of course, the work of some musicians has no sort of bearing, direct or indirect, on religious matters; their personal religious opinions may be what they will, and their musical activities will remain entirely unaffected. But with others it is not so; religion, in some shape, enters into their professional lives. Those who belong to the right wing, whether moderates or extremists, have many refuges to their religious (if not, perhaps, always their artistic) hearts' desires; and the indifferentists can always herd and fend for themselves. It is to the musicians of the left wing that the problem comes.

It may be said indeed that there should really be no problem; or, further, that the right wing has now grown so liberally comprehensive that there should really be no left wing at all. Compromise, it may be arged, is the salt of life; and nowadays nothing more than conformity need be asked of anyone. An adequately robust is better than a valetudinarian conscience, and there are excellent reasons why foundations should not be too curiously explored. Life and art are both far wider than religious formulø: let the musician think about his honest livelihood and his artistic ideals, which he will certainly have as many opportunities of upholding in the church as in the world. All forms of words in these matters, indeed, are by common consent mere approximations : why not, in all good faith, do at Rome as the Romans do? Many things that may look like practical problems belong, we 
are told, to the ephere of the anrealised and the inoperative, surviving only by inertia : it is foolish to worry about them. And, after all, even the unrealised end inoperative atterance of words concerns only the members of a choir : the organist may have nothing even indirectly to do with confessions and creeds, he need not open his mouth unless he likes, need not do a single non-musical thing.

It is all familiar enough, indeed sound enough in its measure, but still . . . Consider the other side. An organist or a choir-member of church or chapel holds his post and performs his duties in the service of a particular religious community, the whole distinctive being of which depends upon its corporate acceptance of particular supernaturalist beliefs expressed in prayers and psalms and hymns and snthems and indeed in everything that its musical servants do, except the organist's " voluntaries" before and after the ritual. These communities are not vaguely comprehensive collections of men of goodwill : so long at least as words are considered to bear any particular meaning, their terms of membership are plain spoken enough. And the situation being so, the authorities of the community might reasonably require always instead of only sometimes that these officials, being responsible for important elements in the community's ritual, should be definite, acting, members of it in as full a signification as any others of its officials. Which indeed seems only common sense, but carries with it as its inevitable corollary this : that no one should start to learn the organ with a view to a professional career unless he is prepared either to confine himself to work independent of the service of any religious community or to take the risk that, at any time, his convictions and a considerable portion of his livelihood may have to part company. The authorities may justly enough hold, if it comes to the point, that for their purposes an inferior artist who believes in the creed that he is doing his share to inculcate is preferable to a superior artist who does not : they cannot be expected to think only of non-religious interests, nor indeed should the organist desire to be treated as a soulless mechanism like his organ. And it is fair enough that the ties should hold outside the official ritual : unlese they can be envianged purely methetically, as is rarely the case, carol-services and Christmes concerts in general are anshakably bond up with the acceptance of the verbal inspiration of a few verses in the first and third Gospels. And apart from music altogether, an organist end his choir may well react religiously on each other in many ways. If the churches and chapels demand of their musical servants more than the mere music, it is not for any musician who takes either his art or himeelf seriously to complain.

But the musician who is not directly or indirectly attached to the 
service of any religious community has every right to complain if he is casnally treated as if he were. The matter need not perhaps affect him individually : when, in 1916 and again in 1919 (on the latter occasion the project was dropped), the Union of Graduates in Masic officially proposed that, as a corporate body, it should attend an ecclesiastical service and transact its pablic business under the ecclesiastical wing, formal protests were very rightly made on behalf of those who, though of course there was no compulsion on their personal presence, resented this assumption of an illegitimate status for the society as a whole. But the musician may ofter enough be individually affected : he may, for example, if a teacher of cless-singing, be forced into a tacit agreement with the Cowper-Temple clause at the least by being required to supervise the preparation of hymns. Similar infractions of conscience-rights are continually being imposed on the ground that they are mere matters of discipline without further implication, that they are, to borrow the phraseology of "World Conferences," matters not of Faith but of Order. Bat after all said and done, the injunction about rendering to Cæsar and the rest of it retains its force, whatever the words in which we may choose to clothe its spirit. And it is for those, in the musical as in any other sphere, who take religion seriously from whatever may be their personal angle to join hands in demanding that some of the most important of all things shall not be lightly and indifferently taken for granted.

But, anyhow, those of the left wing on whom the problem does not press must not throw charges of insincerity at their fellow-musicians on whom it does : it is a hard word, easy to use and rarely to be justified, and the pharisaism of the radical is quite as unlovely as that of the conservative. A man's conscience is his own : and no one else has a right to say how much it ought, or ought not, to stand. Many people, keenly sensible of the importance of these matters, may feel no natural impulse to put two and two together nor to keep their intellectual and ethical activities in non-watertight compartments : many others may feel that, strongly as they may hold to their opinions and clearly realise to what they logically lead, it is rating them too highly to sacrifice for their sake other things of great, possibly greater, value. And, moreover, it is fair enough to arge that, especially in these days when we hear eo much of the Peychology of the Unconscious, we nust recognise that everyone has spheres of anconsciousness which seem unaccountable to those who do happen to be conscious in these particular regards, and that it is not a light moral responsibility to help to bring up into conscionsness some principle thet may gravely disturb the whole complex.

All this is plainly troe: and yet many, increasingly many, cannot 
be satisfied so. However much or however little they may personally decide that their consciences can stand, they cannot surrender their intellectual position, nor let it be carried by default. They must accept the risks, for themselves and perhaps for others. Not that the left-wing musician wants to part company with common-sense. He is, if an Englishman, thankful to belong to a society which takes sufficiently broad views of humen nature to understand that religious differences need not, and should not, cut (as sometimes elsewhere) right across ordinary humen intercourse; nor has he, at any rate outside the service of a religions community, any more hesitation about the public vocal utterance of religions words which he does not accept then about any other singing which may not express his personal feelings." But, temperamentally, he cannot help taking words, formulm, compliances, compromises, more seriously : he cannot assent with an easy mind to any religious tests, even if only implicit, that may happen to come his way. He cannot comfort himself with the idea of the unrealised and inoperative : he feels the conflict, and he also feels that a continual pressure is being silently and perhaps unconsciously, but none the less effectively, exerted against him. He cannot believe in the efficacy of saying "peace, perce," when the facts seem otherwise; nor can he envisage toleration except as a two-sided thing. Whenever the subject of religious teaching in State schools comes up for discussion, we hear of teachers who chafe at the obligation laid on them to teach, whether by commission or omission, what they do not themselves believe : and eimilarly, though we do not hear so much of them, there must be many organists with only a subsidiary interest in the ecclesiastical side of their work who, when accompanying the 120th Psalm to Hopkins in C or the Fourth Tone or anything else, good or bad, must sympathise with its author's lament at being constrained to dwell with Mesech and have his habitation among the tents of Kedar. $\dagger$ Organists are far less important to the community in general than school teachers: nevertheless, they are human beings with the same right as anyone else to the laxury of a conscience. But the musical profession is naturally less concentrated and powerful, and things work more slowly. Before very long, the problem of the freethinking State school-

"If, with Mr. Angustine Birrell in his brilliant essay on "Actors," we are inclined to question the value of a form of human activity of which the casenco is to pretend, we may perheps ang that any singer, in so far as be approsches the actor, is illustrating the inferiority of rocal to instrumental music.

tIf I may perheps be allowed a moment's divergence into personal reminisoence, I may asy that the organistship with which I dwolt in the part wes the minimum and mast tolerant of Mesechs, whose authoritie (from whom my permonal position wa not concealed) never imposed even by implication anj sort of non-musical teat upon me. I am glad to hare decided, come year: ago, to abendon that portion of my work; but the experienco has perhaps its retrospective paychological interest. 
teacher may find its solution in a system of secular education under which the religious teaching of any denomination, including the denomination of undenominationalism, will be left to those who by personal conviction accept it : but it may be longer before school musicteachers are always appointed for the discharge of solely secular duties and non-ecclesiastical organ appointments cease to be the rarities they are now. Still, such ends can always be worked for, by frankness and the stesdy formation of public opinion. If religious duties are fittingly specialised, the whole of the rest of the field will be equally fittingly open to all musicians, independently of any religious tests whatever, explicit or implicit.

No doubt, there is at present something of a tangle, to the musician as to anyone else on the left wing : the one side has had so considerable a start. We all have to remember Johnson's remark to Boswell that, so long as we clear our minds of cant, we need not be over-pedantically anxions to clear our lips of convenient and now conventionally meaningless forms of speech. But the proviso is that we must (and it is not always so very easy) make perfectly sure that these forms of speech really do not now mean anything to anybody. The house of Rimmon has many open doors; but Naaman's mental attitude soems the minimam ethically demandable from any outsider who has to bow the knee in it, and certainly superior to Pascal's advice to the sceptical Chevalier de Meré to act in every way as if he believed, cela vous abêtira. The musician may too long, and by not a few, have been regarded as either an ipso facto conforming servant like Naaman, or, like Pascal's friend, a person of no specially high character; but he has surely won his claim to be judged by the seme intellectual and moral standards as other reasonable folk, and to the possession of his epiritual independence.

Still, if a composer inclines, even in an only moderate measure, to the left wing, his work is often enough supposed to require explanation from the other side. Brahms, we know, did his best to make clear the fact-which on the face of it seems sufficiently obvious-that the Ernste Gesänge were designed by him as a directly anti-orthodox protest $\dagger$ : bat not infrequently, like other things of still more definite tendency, they are commandeered by those who feel it their duty to try to rope all men of genius into the Christian fold, somehow or other, nolentes volentes. While, on the other hand, if the left-wing composer

\footnotetext{
" Bee the more recent editions of the "Pensees."

† Misa May, in her "Life" (ii., 874), explains how they had their origin in the composer's dislike of current evangelicalism; and Kalbeck (in his odition of the Herzogenberg letters), referring to their" "not only antidogmatic but in place altogetber unbelieving" words, mentions that Brahms habitually opoke of them in terms which emphasised their freethinking standpoint.
} 
has been inspired by poetry orthodor in speech but universal in spirit, he is liable to be interpreted, on the spot, with the most rigid literalness. But the comprehensiveness is rarely mutuel. If a composer were to set, without important omissions, Swinburne's Hymn of Man, for example-a poem certainly aniversal in spirit, however unorthodox in apeech-it seems rather doubtful whether the work would have a quite fair chance on its musical merits.

And, whether he wishes to take any sort of overt action or not, the left-wing musician must unflinchingly refuse to be argued by M. Vincent d'Indy* or anyone else out of his conviction that he is quite as capable as any believer of appreciating to the fullest extent all the great religious music ever written. The great work of all the creators in the whole wide field of spirit has its roots, far deeper than any spatial or temporal happenings, down in the mysticism, or whatever we like to call it, by which we chiefly live. What does it matter if we visualise the Sanctus of the B minor Mass with quite other eyes than Bach'e? The forms change and pass ! it is (to quote a phrase from Lord Morley's great book on Compromise) the feeling for the incommensurable things that remains. And in that feeling the freethinking musician must, as confidently as anyone else, claim his inalienable share.

Ernget WalkzB.

* See the finely phrased and transparently sincere confeseion of faith in his "Cours de Composition Musicale" (Introduction, Chepters I. II.), with its insistence on the necesaity of a theistio belief a a minimum for the true musician. 